\title{
The influence of a low-boron diet and boron supplementation on bone, major mineral and sex steroid metabolism in postmenopausal women
}

\author{
BY JOHN H. BEATTIE AND HEATHER S. PEACE \\ Division of Biochemical Sciences, Rowett Research Institute, Bucksburn, Aberdeen AB2 9SB
}

(Received 30 December 1991 - Accepted 4 June 1992)

\begin{abstract}
An increase in dietary intake of $B$ from 0.25 to $3.25 \mathrm{mg} / \mathrm{d}$ has been reported to increase plasma oestradiol and testosterone and decrease urinary $\mathrm{Ca}$ excretion in postmenopausal women. Consequently, it is suggested that the higher level of $B$ intake could reduce bone loss associated with the menopause and cessation of ovarian function. The present study was designed to investigate the effect of a $B$ supplement on bone mineral absorption and excretion, plasma sex steroid levels and urinary excretion of pyridinium crosslink markers of bone turnover in healthy postmenopausal volunteers. The women were accommodated in a metabolic unit, given a low-B diet (LBD; $0.33 \mathrm{mg} / \mathrm{d})$ for 3 weeks and were asked to take a $B$ supplement of $3 \mathrm{mg} / \mathrm{d}$ in addition to the LBD for a further 3 weeks. Changing $B$ intake from 0.33 to $3.33 \mathrm{mg} / \mathrm{d}$ had no effect on minerals, steroids or crosslinks. However, the LBD appeared to induce hyperabsorption of $\mathrm{Ca}$ since positive $\mathrm{Ca}$ balances were found in combination with elevated urinary $\mathrm{Ca}$ excretion. This phenomenon may have inhibited or obscured any effect of $B$.
\end{abstract}

Boron: Calcium: Bone turnover

B is an essential element in many plant species (Jackson \& Chapman, 1975), but there is no firm evidence that it is essential in animals and man. Recent reports suggest that $\mathrm{B}$ may affect bone and Ca metabolism (Nielsen et al. 1988; Hunt, 1989; Beattie \& Macdonald, 1991 ; Hegsted et al. 1991) and there is evidence that supplementation of a low-B diet with $3 \mathrm{mg} \mathrm{B} / \mathrm{d}$ (a total daily $\mathrm{B}$ intake of one to two times the average intake in the UK and USA) can influence the metabolism of major minerals and bone-related hormones in human volunteers, particularly in conditions of $\mathrm{Mg}$ deficiency (Nielsen et al. 1987, 1990). In the former study, Nielsen et al. (1987) gave postmenopausal women a diet low in B $(0.25 \mathrm{mg} / \mathrm{d})$ for $119 \mathrm{~d}$ whereupon they received the same diet but with a supplement of $3 \mathrm{mg} B$ as $\mathrm{Na}_{2} \mathrm{~B}_{4} \mathrm{O}_{7} / \mathrm{d}$ for $48 \mathrm{~d}$. The increase in $\mathrm{B}$ intake from 0.25 to $3.25 \mathrm{mg} / \mathrm{d}$ increased plasma oestradiol and testosterone concentrations and decreased urinary $\mathrm{Ca}$ excretion. A role for $\mathrm{B}$ in the aetiology of osteoporosis was, therefore, proposed and supplements containing B are now sold as remedies for osteoporosis. The findings of Nielsen et al. (1987) are of considerable significance since they imply that hormonal adjustment can be made by changing diet, thus reducing dependence on hormone-replacement therapy, which is unsuitable for some subjects, has side effects and is expensive. However, these proposed implications have yet to be substantiated.

The aim of the present work was, therefore, to assess the effect of changing B intake, by supplementing a low-B diet with $3 \mathrm{mg} \mathrm{B} / 8 \mathrm{MJ}$ energy intake, on plasma sex steroid levels and bone mineral excretion in healthy postmenopausal women. As there is no evidence that $B$ affects human bone and direct measurements are impracticable, changes in bone turnover were assessed by measurement of urinary pyridinium crosslinks. 


\section{METHODS AND MATERIALS \\ Volunteers}

Six volunteers were recruited from over 200 applicants within Scotland. The selection criteria for volunteers was as follows: (1) no current or previous health problems, (2) no prolonged use of drugs for medicinal purposes, particularly steroids, (3) no history of alcohol or drug abuse, (4) no more than 20 years since the menopause, (5) body mass index (weight $/$ height ${ }^{2}$; BMI) close to the average for the 200 volunteer applicants (average BMI 25). Plasma concentrations of oestradiol, progesterone and follicle-stimulating hormone in the selected volunteers confirmed their postmenopausal hormonal status. The physical characteristics of these volunteers are presented in Table 1. All volunteers agreed to the conditions of the study which was approved by the Grampian Health Board Ethical Committee, Aberdeen, Scotland.

The study duration was 6 weeks and the women were accommodated, two at any one time, in the Human Nutrition Unit of the Rowett Research Institute between the months of March and August. The movement of volunteers was restricted to an area surrounding the Institute, although supervised visits outwith this area were organized at weekends. Prolonged exercise was discouraged.

\section{Study protocol}

On arrival at the Unit the volunteers selected food which was representative of their normal diet. The nutritional composition of the six different diets, as calculated from food composition tables (Paul \& Southgate, 1978), was compared with the information obtained from dietary history questionnaires completed during an initial visit to the Unit. The volunteers were allowed this self-selected diet for the first $2 \mathrm{~d}$, which is referred to as the acclimation-period diet (APD). They were then given a diet low in B for the following 3 weeks and the same diet with a daily supplement of $3 \mathrm{mg} \mathrm{B} / 8 \mathrm{MJ}$ energy intake for a further 3 weeks.

Urine samples $(24 \mathrm{~h})$ were collected daily throughout the study in clean plastic bottles containing $1.5 \mathrm{~g}$ ascorbic acid and were stored in a refrigerator. On completion of each $24 \mathrm{~h}$ period the urine volume was measured, the sample was mixed and portions were retained and stored at $-20^{\circ}$. Stool collections were sealed in autoclavable plastic bags and stored at $-20^{\circ}$. Fasted blood samples $(25 \mathrm{ml})$ were obtained in heparinized tubes on Monday, Wednesday and Friday of each week and $1 \mathrm{ml}$ samples of plasma were stored at $-20^{\circ}$.

\section{Diets}

The low-B diet (LBD) consisted of a $3 \mathrm{~d}$ rotating menu (Table 2) and was designed from food tables (Paul \& Southgate, 1978; Koivistoinen, 1980) using a computer dietary analysis program (Microdiet; Salford University, Salford). The energy requirement of each volunteer was calculated from an estimate of basal metabolic rate using weight and height values and a factor of 1.56 to account for physical activity. In certain individuals this calculation underestimated energy requirements, and volunteers who showed a weight loss of more than $20 \mathrm{~g} / \mathrm{kg}$ initial body weight were given a daily supplement of the high-energycarbohydrate supplement (Maxijul; Scientific Hospital Supplies, Liverpool).

The $\mathrm{Ca}$ content of the diet was designed to be the same as the average $\mathrm{Ca}$ intake before the study, which was estimated from the dietary history questionnaires. The nutritional compositions of APD and LBD are compared in Table 3. As the LBD diet was deficient in several minerals and vitamins, supplements in gelatine capsules were taken with each 
Table 1. Physical characteristics of the postmenopausal women

\begin{tabular}{cccccc}
\hline $\begin{array}{c}\text { Subject } \\
\text { no. }\end{array}$ & $\begin{array}{c}\text { Height } \\
(\mathrm{m})\end{array}$ & $\begin{array}{c}\text { Wt } \\
(\mathrm{kg})\end{array}$ & BMI & $\begin{array}{c}\text { Age } \\
\text { (years) }\end{array}$ & $\begin{array}{c}\text { Years after } \\
\text { menopause }\end{array}$ \\
\hline EM & 1.65 & $70 \cdot 6$ & 26.0 & 60 & 15 \\
AO & 1.53 & $61 \cdot 1$ & 26.0 & 65 & 17 \\
MH & 1.56 & $64 \cdot 0$ & 26.2 & 58 & 8 \\
TM & 1.62 & 66.8 & $25 \cdot 4$ & 53 & 5 \\
PR & 1.52 & $51 \cdot 2$ & $22 \cdot 1$ & 57 & 10 \\
MV & 1.54 & $65 \cdot 4$ & 27.8 & 63 & 11 \\
Mean & 1.57 & $63 \cdot 2$ & 25.6 & 59 & 11 \\
\hline
\end{tabular}

BMI, body mass index (weight $/$ height $^{2}$ ).

Table 2. The three daily menus of the low-boron diet

(The menus were rotated throughout the study and the quantities shown are for an $8 \mathrm{MJ}$ intake)

\begin{tabular}{|c|c|c|c|c|c|c|}
\hline \multirow[t]{2}{*}{ Day... } & \multicolumn{2}{|l|}{1} & \multicolumn{2}{|l|}{2} & \multicolumn{2}{|l|}{3} \\
\hline & Food & Wt (g) & Food & Wt (g) & Food & Wt $(g)$ \\
\hline & Cornflakes & 25 & Cornflakes & 25 & Cornflakes & 25 \\
\hline & Sugar & 10 & Sugar & 15 & Sugar & 10 \\
\hline & Marmalade & 10 & Marmalade & 10 & Marmalade & 10 \\
\hline & White bread & 120 & White bread & 120 & White bread & 120 \\
\hline & Boiled ham & 40 & Roast pork & 30 & Liver sausage & 30 \\
\hline & Cod steak & 120 & Edam cheese & 45 & Edam cheese & 40 \\
\hline & White flour & 7 & Cream crackers & 40 & Cream crackers & 55 \\
\hline & Margarine & 34 & Jelly & 100 & Roast beef & 70 \\
\hline & Whole milk & 250 & Chicken, cooked & 50 & Instant potato, dry & 10 \\
\hline & Edam cheese & 45 & Chicken soup, can & 100 & Gravy granules & 4 \\
\hline & Carrot & 10 & Peas & 10 & Jelly & 80 \\
\hline & White rice, boiled & 100 & Shortbread & 55 & Sponge & 50 \\
\hline & Sponge & 50 & Margarine & 37 & Margarine & 30 \\
\hline & Custard creams & 40 & Lemonade & 600 & Custard creams & 20 \\
\hline & Jelly & 50 & Whole milk & 250 & Whole milk & 250 \\
\hline & Lemonade & 500 & & & Lemonade & 500 \\
\hline \multicolumn{3}{|c|}{ Two teabags } & \multicolumn{2}{|l|}{ Two teabags } & \multicolumn{2}{|l|}{ Two teabags } \\
\hline
\end{tabular}

meal to meet UK recommended daily allowances (RDA). The USA RDA was used where no recommended level has been set in the UK.

The diet was also low in fibre and the women were given a commercial sterculia-gumfibre supplement (Normacol; Norgine Ltd, Headington, Oxford). The daily total fibre intake was, therefore, $24 \mathrm{~g} / 8 \mathrm{MJ}$ energy intake. The fibre supplement was found to contain calcium and magnesium silicates which contributed an additional $148 \mathrm{mg}$ Ca and $280 \mathrm{mg}$ $\mathrm{Mg} / \mathrm{d}$; however, in this form $\mathrm{Ca}$ and $\mathrm{Mg}$ are insoluble and probably unavailable. Radioopaque markers enclosed in gelatine capsules were provided with each meal to give a total marker intake of $40 / \mathrm{d}$. The marker shape was changed each week so that $7 \mathrm{~d}$ faecal output could be identified.

All foods were accurately dispensed into clean plastic containers and were covered and stored at $-20^{\circ}$ until required. Microwave ovens were used for heating meals in their 
Table 3. Daily energy and nutrient intake of postmenopausal women on the acclimationperiod diet $(A P D)$ and the low-boron diet $(L B D)$ as calculated from food composition tables (Paul \& Southgate, 1978)*

\begin{tabular}{|c|c|c|c|c|c|c|}
\hline \multirow[b]{2}{*}{ Nutrient } & \multicolumn{2}{|c|}{ APD } & \multicolumn{4}{|c|}{ LBD } \\
\hline & Mean & Range & $\begin{array}{l}\text { Diet } \\
\text { mean }\end{array}$ & $\begin{array}{l}\text { Supplement } \\
\text { mean }\end{array}$ & $\begin{array}{l}\text { Total } \\
\text { mean }\end{array}$ & $\begin{array}{l}\text { Total } \\
\text { range }\end{array}$ \\
\hline Energy $(\mathrm{MJ})$ & $7 \cdot 69$ & $4 \cdot 87-9 \cdot 12$ & 7.95 & $\ddagger$ & 7.95 & $7 \cdot 20-8.50$ \\
\hline Protein (g) & 62 & $39-86$ & 66 & - & 66 & $59-70$ \\
\hline Fat $(\mathrm{g})$ & 85 & $51-123$ & 84 & - & 84 & $76-89$ \\
\hline Carbohydrate (g) & 208 & $108-303$ & 232 & $\ddagger$ & 232 & $210-248$ \\
\hline Dietary fibre (g) & $21 \cdot 7$ & $11 \cdot 3-29 \cdot 1$ & $11 \cdot 0$ & $12 \cdot 8 \dagger$ & $23 \cdot 8$ & $21 \cdot 6-25 \cdot 5$ \\
\hline $\mathrm{Ca}(\mathrm{mg})$ & 836 & $510-1124$ & 927 & - & 927 & $840-991$ \\
\hline $\mathrm{Mg}(\mathrm{mg})$ & 299 & $185-419$ & 130 & 168 & 298 & $270-319$ \\
\hline $\mathrm{P}(\mathrm{mg})$ & 1141 & $785-1408$ & 980 & - & 980 & $887-1048$ \\
\hline $\mathrm{K}(\mathrm{mg})$ & 3015 & $1913-4507$ & 1149 & - & 1149 & $1040-1228$ \\
\hline $\mathrm{S}(\mathrm{mg})$ & 483 & $215-675$ & 465 & 223 & 688 & $619-731$ \\
\hline B (mg) & ID & & $0 \cdot 33$ & $2.98 \S$ & $3 \cdot 31 \S$ & $3.00-3.54$ \\
\hline $\mathrm{Fe}(\mathrm{mg})$ & $11 \cdot 3$ & $7 \cdot 0-36 \cdot 0$ & 6.7 & $3 \cdot 3$ & $9 \cdot 9$ & $9 \cdot 0-10 \cdot 6$ \\
\hline $\mathrm{Zn}(\mathrm{mg})$ & $7 \cdot 3$ & $4 \cdot 9-10 \cdot 2$ & $7 \cdot 0$ & 2.9 & $9 \cdot 9$ & $9 \cdot 0-10 \cdot 6$ \\
\hline $\mathrm{Cu}(\mathrm{mg})$ & $1 \cdot 25$ & $0.86-1.71$ & 0.67 & 1.82 & $2 \cdot 49$ & $2 \cdot 25-2 \cdot 66$ \\
\hline Ascorbic acid (mg) & $87 \cdot 8$ & $9 \cdot 4-286$ & $5 \cdot 6$ & $53 \cdot 8$ & $59 \cdot 4$ & $54 \cdot 0-63 \cdot 8$ \\
\hline Folic acid (mg) & 166 & $98-288$ & $0 \cdot 8$ & $0 \cdot 2$ & $1 \cdot 0$ & $0.91-1.07$ \\
\hline
\end{tabular}

ID, insufficient information

* For details of dietary regimen, see pp. 872-873.

$\dagger$ Fibre supplement was found to contain calcium and magnesium silicates which contributed an additional $148 \mathrm{mg} \mathrm{Ca}$ and $280 \mathrm{mg} \mathrm{Mg} / \mathrm{d}$; however, in this form Ca and $\mathrm{Mg}$ are insoluble and probably unavailable.

\$ Carbohydrate supplement, Maxijul (Scientific Hospital Supplies, Liverpool), supplied to three volunteers to prevent weight loss.

$\S$ Supplement provided during the second period of 3 weeks only (for details, see p. 872).

original containers and clean plastic cutlery and cups were provided. The volunteers were asked to clean the food containers with bread from the diet to ensure complete ingestion of each meal. Distilled water was freely available and multiple use of the tea bags was allowed.

\section{Analyses}

Diet. The foods in each LBD daily menu were pooled and homogenized with distilled water. The homogenates included infusions of the two tea bags with hot distilled water. Samples of the homogenized foods were freeze-dried and ground to a powder. $\mathrm{Ca}, \mathrm{Mg}$ and $P$ concentrations were determined by $X$-ray fluorescence spectroscopy using compressed pellets of the food powder.

For the measurement of B in LBD or its constituent foods, $200 \mathrm{mg}$ samples of freezedried powder were digested in $\mathrm{HNO}_{3}(800 \mathrm{ml} / \mathrm{l})$ in a microwave digestion vessel (Parr Instrument Co., Moline, IL, USA) using a domestic $750 \mathrm{~W}$ microwave oven. These vessels do not vent under normal operating conditions and are recommended by the manufacturer for digestion of samples where volatile elements such as B are to be measured. B was analysed by inductively coupled plasma optical emission spectroscopy (ICP/OES).

Faeces. The sealed bags of faeces were autoclaved and X-rayed to identify the number and shape of radio-opaque markers in each collection. Recovery of markers ranged from 96-101\%. Those collections containing markers of two different shapes representing the transition between two $7 \mathrm{~d}$ periods were pooled. Similarly, the faecal collections with only 
one type of marker present were pooled. The faeces were homogenized with deionized water and portions were freeze-dried and ground to a fine powder. $\mathrm{Ca}, \mathrm{Mg}$ and $\mathrm{P}$ concentrations were analysed directly by X-ray fluorescence spectroscopy.

Urine. The concentrations of $\mathrm{Ca}$ and $\mathrm{Mg}$ were measured colorimetrically (Gitelman et al. 1966; Gitelman, 1967) and P was determined by the method of Fiske \& Subbarow (1925). The samples were also analysed for B using ICP/OES.

For the measurement of pyridinium crosslinks, total pyridinoline and deoxypyridinoline were extracted from urine and separated using the method of Black et al. (1989). In brief, samples of each $24 \mathrm{~h}$ urine collection were hydrolysed in $5.5 \mathrm{M}-\mathrm{HCl}$ for $18 \mathrm{~h}$ at $107^{\circ}$. The pyridinium crosslinks were extracted from the hydrolysates by partition chromatography on cellulose $\mathrm{CF} 1$ and then separated by HPLC on a $\mathrm{C}_{18}$ column using a linear gradient of

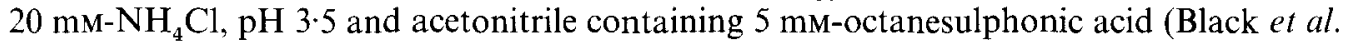
1989). The eluting crosslinks were detected by fluorescence spectroscopy with excitation at $295 \mathrm{~nm}$ and emission at $400 \mathrm{~nm}$.

Creatinine was determined by the Jaffe reaction (Bosnes \& Taussky, 1945).

Plasma. Plasma total testosterone was measured by radioimmunoassay (RIA) using a commercial kit (Serono Diagnostic Ltd, Woking, Surrey). A commercial RIA kit (RSL direct ${ }^{125}$ I-[estradiol-17 $\beta$ ]-RIA kit; ICN Biomedicals Inc., Carson, CA, USA) was also used for the determination of plasma total oestradiol but, because of the low concentrations, the calibration curve included additional standards over the range $5-30 \mathrm{pg} / \mathrm{ml}$. This direct RIA kit requires $50 \mu \mathrm{l}$ plasma or serum, although for validation of the results (see p. 880), volumes of $50,63,75,88$ and $100 \mu l$ were used for each plasma sample in the present study.

\section{Statistics}

A two-way analysis of variance (ANOVA; subject and sample time) was used to test for differences in urinary bone mineral excretion between successive $7 \mathrm{~d}$ periods throughout the study. The values for the $7 \mathrm{~d}$ periods for plasma testosterone and urinary pyridinium crosslinks and also the $7 \mathrm{~d}$ bone mineral balance values were analysed in the same way. All computations were made using Minitab statistical software. Comparison of mean data was made by calculating $t$ values from the ANOVA error mean square.

\section{RESULTS \\ Boron in food}

As shown in Table 4, B levels in the foods selected for LBD were generally higher than those reported for Finnish foods (Koivistoinen, 1980). The mean daily B content of the $3 \mathrm{~d}$ rotating menu was $0.33 \mathrm{mg} / 8 \mathrm{MJ}$ energy intake.

\section{Urinary calcium, magnesium and phosphorous}

Urinary $\mathrm{Ca}$ excretion increased rapidly following the transition from APD to LBD and in several cases more than doubled. This high level of excretion was maintained throughout the 6-week study and was unaffected by B supplementation (Table 5). To verify these results, which indicated diet-induced hypercalciuria, the urine samples were treated with $\mathrm{LaCl}_{3}$ and re-analysed for $\mathrm{Ca}$ using atomic absorption spectrophotometry. The values obtained by this method (results not shown) were similar to those obtained with the colorimetric assay.

Urinary $\mathrm{Mg}$ excretion followed a similar pattern to $\mathrm{Ca}$ except that the initial elevation 
Table 4. The boron content of selected foods: comparison of food composition table values* with present analyses

\begin{tabular}{|c|c|c|}
\hline Food & $\begin{array}{c}\text { Analysed } \\
(\mathrm{mg} \mathrm{B} / \mathrm{kg})\end{array}$ & $\begin{array}{l}\text { Published* } \\
\text { (mg B/kg) }\end{array}$ \\
\hline Peas, frozen & $3 \cdot 1$ & $1 \cdot 8$ \\
\hline Carrots & $4 \cdot 6$ & $3 \cdot 2$ \\
\hline Wholemeal bread & $1 \cdot 0$ & 0.5 (estimation) \\
\hline Brussel sprouts & $3 \cdot 8$ & No value \\
\hline Edam cheese & $0 \cdot 5$ & $<0.3$ \\
\hline Cornflakes & $0 \cdot 6$ & 0.7 \\
\hline Cod, frozen & $0 \cdot 4$ & $0 \cdot 2$ \\
\hline Milk & $0 \cdot 3$ & $0 \cdot 2$ \\
\hline White bread & 0.6 & 0.5 \\
\hline Broccoli & $7 \cdot 2$ & $4 \cdot 6$ \\
\hline Potato powder & $4 \cdot 2$ & 3.7 \\
\hline Banana & $2 \cdot 6$ & 1.7 \\
\hline
\end{tabular}

* Values calculated from the food composition tables of Koivistoinen (1980).

Table 5. Urinary mineral excretion of postmenopausal women on the day before starting the low-boron diet (baseline) and throughout the study $\dagger$

(Mean values and standard deviations for daily collections, except for baseline values)

\begin{tabular}{|c|c|c|c|c|c|c|}
\hline \multirow[b]{2}{*}{ Week } & \multicolumn{2}{|c|}{$\mathrm{Ca}(\mathrm{mg} / \mathrm{d})$} & \multicolumn{2}{|c|}{$\mathrm{Mg}(\mathrm{mg} / \mathrm{d})$} & \multicolumn{2}{|c|}{$P(\mathrm{mg} / \mathrm{d})$} \\
\hline & Mean & SD & Mean & SD & Mean & SD \\
\hline Baselinet & $132 \cdot 5$ & 47.6 & $81 \cdot 0$ & $25 \cdot 5$ & $749 \cdot 5$ & $245 \cdot 6$ \\
\hline 1 & $239 \cdot 1^{*}$ & $79 \cdot 7$ & $108 \cdot 3$ & $27 \cdot 1$ & $577 \cdot 7$ & 103.4 \\
\hline 2 & $258 \cdot 7$ & $77 \cdot 0$ & $115 \cdot 4$ & $26 \cdot 6$ & $541 \cdot 5$ & $79 \cdot 9$ \\
\hline 3 & $263 \cdot 2$ & $74 \cdot 4$ & 115.6 & $24 \cdot 8$ & $544 \cdot 1$ & 76.7 \\
\hline 4 & $260 \cdot 9$ & $74 \cdot 7$ & 112.3 & 21.9 & $549 \cdot 4$ & $70 \cdot 6$ \\
\hline 5 & $265 \cdot 0$ & $76 \cdot 1$ & $115 \cdot 6$ & $20 \cdot 6$ & $544 \cdot 6$ & 70.8 \\
\hline 6 & $264 \cdot 1$ & $66 \cdot 9$ & $117 \cdot 1$ & $26 \cdot 3$ & $549 \cdot 6$ & $88 \cdot 3$ \\
\hline
\end{tabular}

* Mean value was significantly different from baseline value: $P<0.005$.

$\dagger$ For details of diets and procedures, see Table 2 and pp. 872-873.

$\ddagger$ Baseline values are not included in ANOVA.

was less marked. Urinary excretion of $P$, however, decreased slightly during the initial $3 \mathrm{~d}$ period and then stabilized; it was not affected by $\mathbf{B}$ (Table 5).

\section{Plasma sex steroids}

Plasma testosterone concentrations varied markedly between subjects but were unaffected by $\mathbf{B}$ supplementation (Table 6 ).

Plasma oestradiol proved difficult to measure by any commercial or 'in-house' RIA method due to the low circulating levels of this steroid in postmenopausal women. Nielsen et al. (1987) used a direct commercial assay kit to measure oestradiol in postmenopausal plasma and so the same kit has been used in the present study. In accordance with the procedure adopted by Nielsen and colleagues (S. K. Gallagher, personal communication), a calibration curve was constructed to extend the normal range of the assay below $10 \mathrm{pg} / \mathrm{ml}$. This was accomplished by diluting the supplied oestradiol standards with the zero standard. All samples and standards were dispensed in duplicate using electronic pipettes in multidispense mode to minimize pipetting inaccuracy. A linear standard curve 
Table 6. Plasma sex steroid levels of postmenopausal women determined immediately before starting the low-boron diet (baseline) and at the end of each week throughout the study*

\begin{tabular}{|c|c|c|c|c|c|c|c|}
\hline \multicolumn{2}{|c|}{ B intake $(\mathrm{mg} / \mathrm{d}) \ldots$} & \multicolumn{3}{|c|}{$0 \cdot 33$} & \multicolumn{3}{|c|}{$3 \cdot 33$} \\
\hline Subject & Baseline & Week 1 & Week 2 & Week 3 & Week 4 & Week 5 & Week 6 \\
\hline \multicolumn{8}{|c|}{ Testosterone $(\mathrm{ng} / \mathrm{ml})$} \\
\hline EM & $0 \cdot 780$ & 0.997 & 0.658 & 0.737 & $0 \cdot 745$ & $0 \cdot 800$ & 0.822 \\
\hline TM & 0.273 & $0 \cdot 330$ & $0 \cdot 278$ & 0.291 & $0 \cdot 330$ & $0 \cdot 267$ & $0 \cdot 306$ \\
\hline $\mathrm{AO}$ & 0.132 & $0 \cdot 177$ & $0 \cdot 208$ & $0 \cdot 185$ & $0 \cdot 142$ & $0 \cdot 154$ & $0 \cdot 128$ \\
\hline PR & 0.396 & $0 \cdot 434$ & $0 \cdot 438$ & 0.483 & 0.507 & 0.443 & 0.451 \\
\hline MH & $0 \cdot 114$ & $0 \cdot 054$ & 0.034 & 0.040 & $0 \cdot 103$ & 0.095 & 0.023 \\
\hline MV & 0.264 & $0 \cdot 261$ & $0 \cdot 253$ & $0 \cdot 316$ & $0 \cdot 290$ & 0.219 & $0 \cdot 270$ \\
\hline Mean & $0-330$ & $0 \cdot 376$ & $0 \cdot 312$ & $0-342$ & $0 \cdot 353$ & $0 \cdot 330$ & $0-333$ \\
\hline $\mathrm{SD}$ & 0.242 & $0 \cdot 331$ & $0 \cdot 214$ & $0 \cdot 243$ & $0 \cdot 240$ & 0.259 & $0 \cdot 281$ \\
\hline \multicolumn{8}{|c|}{ Oestradiol $(\mathrm{pg} / \mathrm{ml}) \dagger$} \\
\hline EM & $10 \cdot 3$ & $7 \cdot 2$ & $7 \cdot 1$ & $7 \cdot 0$ & 5 & $7 \cdot 3$ & $12 \cdot 3$ \\
\hline $\mathrm{TM}$ & 2 & 2 & $<1$ & 4 & $<1$ & 3 & 3 \\
\hline $\mathrm{AO}$ & $7 \cdot 6$ & $5 \cdot 3$ & $7 \cdot 3$ & 5 & 4 & 6.4 & $8 \cdot 2$ \\
\hline PR & $6 \cdot 1$ & 3 & 4 & 5 & 2 & $<1$ & $<1$ \\
\hline MH & 110 & $5 \cdot 1$ & $10 \cdot 1$ & $9-4$ & 60 & $10 \cdot 1$ & 8.8 \\
\hline MV & $10 \cdot 1$ & 3 & 1 & 3 & $6 \cdot 7$ & 2 & 2 \\
\hline
\end{tabular}

* For details of diets and procedures, see Table 2 and pp. 872-875.

$\dagger$ Values for oestradiol which were below the lowest standard $(5 \mathrm{pg} / \mathrm{ml})$ are shown as the nearest whole number.

Table 7. Urinary pyridinium crosslink excretion (nmol/mmol creatinine) of postmenopausal women measured in $24 \mathrm{~h}$ urine samples collected 1 d before starting the low-boron diet (baseline), on the first day of the study (DI) and at the end of each week throughout the study*

\begin{tabular}{|c|c|c|c|c|c|c|c|c|}
\hline \multicolumn{2}{|c|}{ B intake $(\mathrm{mg} / \mathrm{d}) \ldots$} & \multicolumn{4}{|c|}{0.33} & \multicolumn{3}{|c|}{$3 \cdot 33$} \\
\hline Subject & Baseline & D1 & Week 1 & Week 2 & Week 3 & Week 4 & Week 5 & Week 6 \\
\hline \multicolumn{9}{|c|}{ Pyridinoline } \\
\hline EM & $28 \cdot 8$ & $19 \cdot 6$ & $24 \cdot 2$ & $16 \cdot 6$ & $40 \cdot 0$ & $21 \cdot 0$ & 27.0 & $21 \cdot 8$ \\
\hline $\mathrm{AO}$ & $18 \cdot 2$ & $17 \cdot 2$ & $21 \cdot 3$ & $23 \cdot 6$ & $32 \cdot 6$ & $19 \cdot 9$ & $14 \cdot 5$ & $18 \cdot 8$ \\
\hline $\mathrm{MH}$ & $43 \cdot 3$ & $31 \cdot 0$ & $41 \cdot 8$ & $28 \cdot 1$ & $28 \cdot 5$ & $39 \cdot 2$ & $28 \cdot 4$ & $38 \cdot 2$ \\
\hline $\mathrm{TM}$ & $52 \cdot 0$ & $48 \cdot 6$ & $44 \cdot 1$ & $45 \cdot 1$ & $36 \cdot 8$ & $31 \cdot 1$ & $35 \cdot 3$ & $28 \cdot 2$ \\
\hline PR & $27 \cdot 6$ & $26 \cdot 4$ & 26.9 & $23 \cdot 2$ & $28 \cdot 3$ & $27 \cdot 9$ & $22 \cdot 9$ & $27 \cdot 6$ \\
\hline MV & $30 \cdot 3$ & $28 \cdot 5$ & $36 \cdot 4$ & $32 \cdot 5$ & $36 \cdot 7$ & $31 \cdot 6$ & $37 \cdot 4$ & $37 \cdot 3$ \\
\hline Mean & $33 \cdot 4$ & $28 \cdot 6$ & $32 \cdot 5$ & $28 \cdot 2$ & 33.8 & $28 \cdot 5$ & $27 \cdot 6$ & $28 \cdot 7$ \\
\hline SD & $12 \cdot 2$ & $11 \cdot 1$ & $9 \cdot 6$ & $9 \cdot 8$ & 48 & $7 \cdot 2$ & $8 \cdot 4$ & $7 \cdot 9$ \\
\hline \multicolumn{9}{|c|}{ Deoxypyridinoline } \\
\hline EM & $11 \cdot 6$ & 4.7 & $5 \cdot 0$ & $3 \cdot 5$ & 106 & $3 \cdot 9$ & $6 \cdot 1$ & $5 \cdot 1$ \\
\hline $\mathrm{AO}$ & $4 \cdot 7$ & 3.7 & $4 \cdot 2$ & $4 \cdot 7$ & $11 \cdot 3$ & $5 \cdot 3$ & $5 \cdot 0$ & $5 \cdot 4$ \\
\hline MH & $8 \cdot 2$ & $11 \cdot 3$ & $14 \cdot 2$ & $8 \cdot 3$ & 8.7 & $8 \cdot 8$ & $7 \cdot 1$ & 9.8 \\
\hline TM & $18 \cdot 1$ & $11 \cdot 3$ & $12 \cdot 5$ & $13 \cdot 6$ & 106 & $9 \cdot 1$ & $10 \cdot 8$ & $8-0$ \\
\hline PR & 13.9 & 14.6 & $12 \cdot 5$ & $10 \cdot 2$ & $12 \cdot 1$ & $15 \cdot 5$ & $20 \cdot 3$ & $11 \cdot 6$ \\
\hline MV & $13 \cdot 0$ & $11 \cdot 0$ & $15 \cdot 3$ & $12 \cdot 1$ & 12.9 & $10 \cdot 6$ & $9 \cdot 3$ & $13 \cdot 5$ \\
\hline Mean & $11 \cdot 6$ & $9 \cdot 4$ & $10 \cdot 6$ & 8.7 & 11.0 & 8.8 & $9 \cdot 8$ & $8 \cdot 9$ \\
\hline $\mathrm{SD}$ & $4 \cdot 7$ & $4 \cdot 3$ & $4 \cdot 8$ & 40 & 1.5 & $4 \cdot 1$ & 5.6 & $3 \cdot 4$ \\
\hline
\end{tabular}

* For details of diets and procedures, see Table 2 and pp. 872-873. 


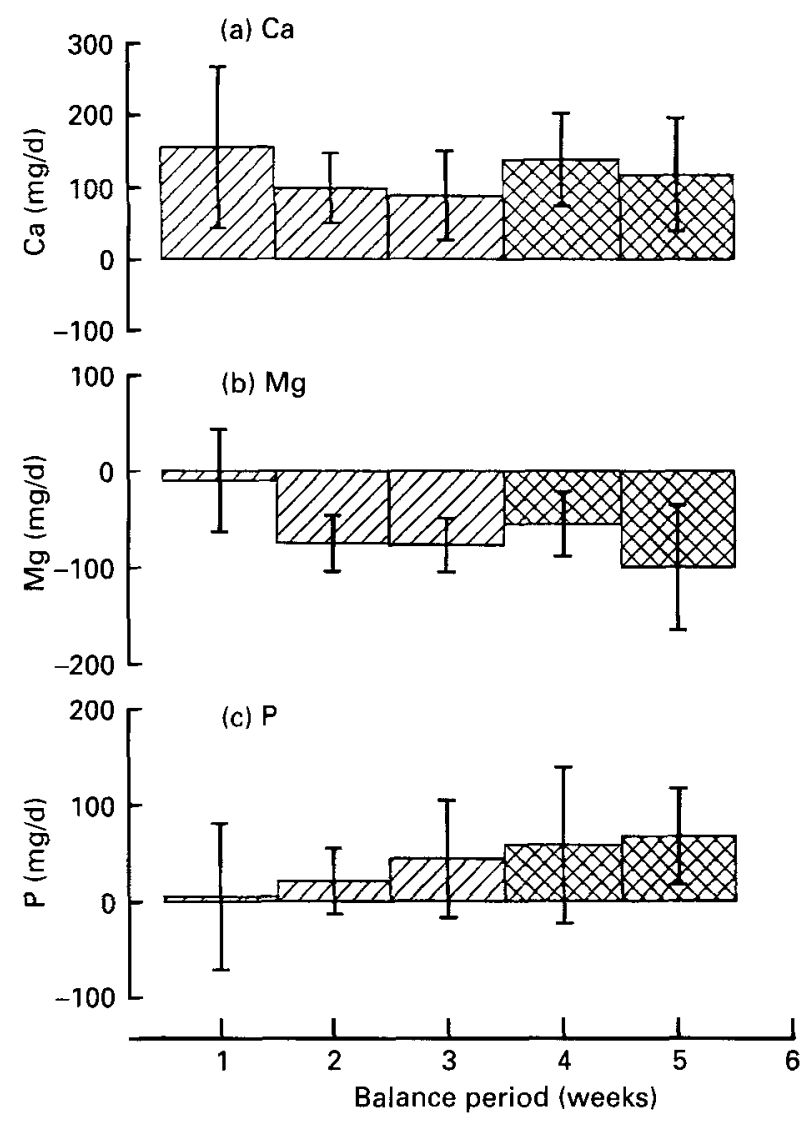

Fig. 1. Successive $7 \mathrm{~d}$ mineral balances for healthy postmenopausal women on a low boron diet (国) and subsequently on the same diet with a B supplement (畻). Values are the means and standard deviation represented by vertical bars for six volunteers. For details of diets and procedures, see Table 2 and pp. 872-875.

Table 8. Detailed mineral balance values for postmenopausal volunteer TM $(\mathrm{mg} / \mathrm{d})^{*}$

\begin{tabular}{|c|c|c|c|c|c|c|c|c|c|}
\hline \multirow[b]{2}{*}{ Mineral } & \multirow[b]{2}{*}{ Week } & \multicolumn{4}{|c|}{ Mineral intake } & \multicolumn{3}{|c|}{ Mineral excretion } & \multirow[b]{2}{*}{ Balance } \\
\hline & & Food & Normacol & Supplement & Total & Urine & Faeces & Total & \\
\hline \multirow[t]{5}{*}{$\mathrm{Ca}$} & 1 & 1054 & 148 & - & 1202 & 204 & 840 & 1044 & +158 \\
\hline & 2 & 1064 & 148 & - & 1212 & 224 & 855 & 1079 & +133 \\
\hline & 3 & 1051 & 148 & - & 1199 & 236 & 927 & 1163 & +36 \\
\hline & 4 & 1054 & 148 & $\ldots$ & 1202 & 234 & 872 & 1106 & +96 \\
\hline & 5 & 1064 & 148 & - & 1212 & 240 & 902 & 1142 & +70 \\
\hline \multirow[t]{5}{*}{$\mathrm{Mg}$} & 1 & 128 & 280 & 169 & 577 & 124 & 466 & 590 & -13 \\
\hline & 2 & 127 & 280 & 169 & 576 & 146 & 502 & 648 & -72 \\
\hline & 3 & 127 & 280 & 169 & 576 & 135 & 531 & 666 & -90 \\
\hline & 4 & 128 & 280 & 169 & 577 & 128 & 505 & 633 & -56 \\
\hline & 5 & 127 & 280 & 169 & 576 & 130 & 562 & 692 & -166 \\
\hline \multirow[t]{5}{*}{$P$} & 1 & 983 & - & - & 983 & 600 & 461 & 1061 & -78 \\
\hline & 2 & 973 & - & - & 973 & 548 & 441 & 989 & -16 \\
\hline & 3 & 970 & - & - & 970 & 515 & 464 & 979 & -9 \\
\hline & 4 & 983 & - & - & 983 & 510 & 447 & 957 & +26 \\
\hline & 5 & 973 & - & - & 973 & 505 & 460 & 965 & $\begin{array}{l}28 \\
+8\end{array}$ \\
\hline
\end{tabular}

* For details, see Table 1. 


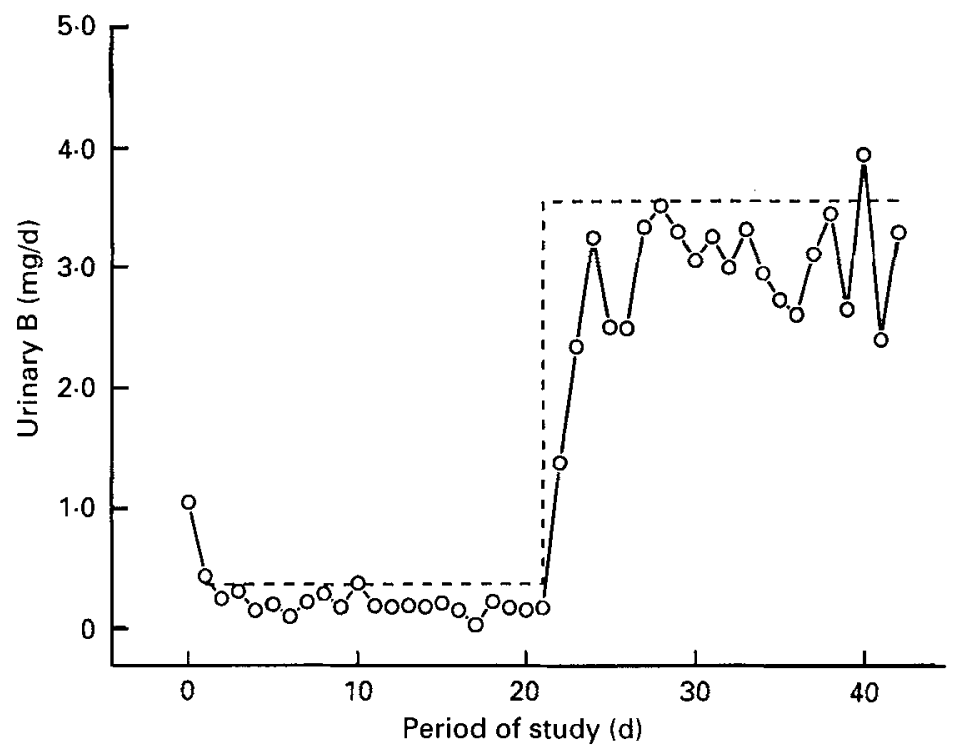

Fig. 2. Urinary boron excretion $(\mathrm{O}-\mathrm{O})$ for one healthy postmenopausal volunteer throughout the 6-week study. Time 0 represents $B$ excretion on the day before starting the low-B diet. (- - , B intake.

with a correlation coefficient of 0.9913 was obtained from five standards within the range $5-30 \mathrm{pg} / \mathrm{ml}$. Plasma oestradiol levels were generally within the range $1-12 \mathrm{pg} / \mathrm{ml}$ (Table 6 ). All values below the lower limit of the standard curve are expressed only to the nearest whole number. As discussed later (pp. 880-881), these results are tentative but are included for comparison with the results of Nielsen et al. (1987) who used the same method. Oestradiol levels tended to decrease on LBD but did not change consistently after $B$ supplementation.

\section{Urinary pyridinium crosslinks}

The urinary excretion of pyridinoline and deoxypyridinoline was relatively constant throughout the study and was unaffected by $\mathrm{B}$ supplementation. There were, however, marked differences between volunteers in urinary crosslink concentrations (Table 7).

\section{Bone mineral balances}

Faecal mineral excretion for successive $7 \mathrm{~d}$ periods was calculated as the sum of total minerals excreted during the clear marker periods (radio-opaque markers of uniform shape) with a proportion of minerals from the mixed-marker periods representing the transition from one balance period to the next. The amount of minerals in the mixedmarker periods was apportioned according to the ratio of marker shapes. Balances were calculated by subtracting the sum of faecal and urinary mineral excretion from the total intake of minerals in food and supplements during the balance period. An example of the contribution of minerals from different sources is shown in Table 8.

All volunteers were in positive Ca balance throughout the study (Fig. 1). The balance for week 6 has been omitted since the faecal collections for this period were incomplete. In addition, the first week's balance in each 3-week dietary period has been regarded as an acclimation period. However, comparison of week 2 with week 5 shows no significant effect of $\mathrm{B}$ on $\mathrm{Ca}$ balance.

With each successive balance period, $P$ balance became increasingly positive whereas the converse was true for $\mathrm{Mg}$ balance (Fig. 1). Supplementation with $\mathrm{B}$ had no clear effect on $\mathrm{P}$ and $\mathrm{Mg}$ balance. 


\section{Urinary boron}

The urinary excretion of B reflected the dietary intake of the element (Fig. 2). It decreased within $48 \mathrm{~h}$ of starting LBD and then stabilized. Similarly, urinary B excretion increased very rapidly after the $B$ supplement was given and stabilized at more than $90 \%$ of total $B$ intake.

\section{DISCUSSION}

Nielsen et al. (1987) have reported a significant increase in plasma testosterone and oestradiol levels within $8 \mathrm{~d}$ of supplementing postmenopausal women with the same level of $\mathbf{B}$ used in the present study. The study of Nielsen et al. (1987) was conducted on subjects who had been on a low-B diet for $119 \mathrm{~d}$ and the effect of B supplementation was enhanced when the diet was deficient in $\mathrm{Mg}$. These authors suggest that B may exert its influence through interaction with some hormones and enzyme reactions. A mechanism for B-oestrogen interactions has been proposed (Beattie \& Weersink, 1992) in which borate has its effect by forming a complex with the vicinal hydroxyl groups of catechol oestrogens, thus limiting subsequent methylation and changing the rate or pathway for the catabolism and excretion of the major oestrogens. Such a mechanism, analogous to that proposed by Humphries (see Bremner, 1991), for Mo effects on sex hormone metabolism in cattle could have led to an increase in plasma oestrogen concentrations.

The plasma oestradiol level recorded by Nielsen et al. (1987) after giving a B supplement of $3 \mathrm{mg} / \mathrm{d}$ with a low-B, Mg-deficient diet was approximately $41 \mathrm{pg} / \mathrm{ml}$ compared with $21 \mathrm{pg} / \mathrm{ml}$ on the basal diet alone $(0.25 \mathrm{mg} \mathrm{B} / \mathrm{d})$. This B-related increase in plasma oestradiol was less marked on a $\mathrm{Mg}$-adequate diet but evident nevertheless. In the present study oestradiol values obtained using a commercial direct RIA kit were considerably lower than those reported by Nielsen et al. (1987) who used the same assay kit. The present values were also lower than initial results obtained with an 'in-house' RIA (Peace \& Beattie, 1991) and a significant proportion were below the standard range of the assay kit. In addition to poor precision and questionable accuracy at these low levels, cross-reactivity of the antibody with other oestrogens, oestrone in particular, and wide fluctuations in plasma levels of oestradiol in postmenopausal women could result in spurious or misleading results. After confirming the linearity of the relationship between assay sample volume and apparent oestrogen level using both pre- and postmenopausal plasma, we routinely assayed five different volumes, namely $50,63,75,88$ and $100 \mu \mathrm{l}$, of each plasma sample. The regression slope for postmenopausal samples was consistently greater than 1 and the larger volumes gave apparent oestrogen values which were well within the standard range of the assay. Taking advantage of the improved precision of these values we were able to assess, by regression, the accuracy of the analysis with $50 \mu 1$ (the recommended assay sample volume).

The antibody supplied by ICN Biochemicals Inc. had a specified cross-reactivity with oestrone of $20 \%$, and this was confirmed by our own tests. Since oestrone is the principal oestrogen in postmenopausal plasma and is present at approximately three times the concentration of oestradiol-17 $\beta$ (Reed \& Murray, 1979), then almost $40 \%$ of the oestrogen value obtained with this or similar kits could be attributable to the presence of oestrone. Changes in the levels recorded could, therefore, be interpreted as an effect on oestradiol, oestrone or both oestrogens.

Of concern in the determination of oestradiol levels in postmenopausal plasma are the wide and apparently random fluctuations in the concentrations during a $24 \mathrm{~h}$ period. In studies where blood samples were obtained from postmenopausal volunteers every $20 \mathrm{~min}$ for $24 \mathrm{~h}$, oestradiol was found to change markedly by as much as a factor of two, even between sequential samples (Hutton et al. 1979). Rae et al. (1988) have discussed the 
problems associated with measuring plasma oestradiol in postmenopausal women and suggest that it is more appropriate to determine urinary oestrogens from $24 \mathrm{~h}$ collections.

Conclusions concerning the influence of a B supplement on oestradiol levels in postmenopausal plasma based on the results obtained by commercial direct RIA kits must, therefore, be regarded as tentative. In the present study there was suggestion of a decrease in oestrogen levels when starting LBD, an effect which was abolished towards the end of the study in two of the volunteers. This effect could be due to B but may equally be related to homeostatic adaptation to changes in other components of the diet.

Postmenopausal plasma testosterone concentrations, which are more readily determined using commercial RIA kits, were unaffected by an increase in dietary B intake from 0.33 to $3.33 \mathrm{mg} / \mathrm{d}$. This result conflicts with that obtained by Nielsen et al. (1987), who also used a commercial RIA kit for testosterone analysis and found that the plasma level of this steroid increased from 0.31 to $0.83 \mathrm{ng} / \mathrm{ml}$ in response to $B$ supplementation.

The present study was designed in the expectation that the combined monitoring of sex steroids and pyridinium crosslinks might link hormonal effects with changes in bone turnover. Black et al. (1989) have reported that ovariectomized rats have a higher deoxypyridinoline excretion than a sham-operated control group. Also, a decrease in pyridinium crosslink excretion was observed in postmenopausal women given hormonereplacement therapy (Ubelhardt et al. 1991). Other studies (Seibel et al. 1989; Robins et al. 1991) have shown the validity of monitoring deoxypyridinoline excretion as an index of bone turnover. Recent findings show a higher deoxypyridinoline output in osteoporotics (Robins et al. 1990), which supports the concept that the excretion of non-reutilizable crosslinks from type I collagen in bone is a good indicator of normal and pathophysiological modulation of bone turnover. Thus, the constancy of the deoxypyridinoline excretion in the women throughout the present 6-week study strongly suggests a constant rate of bone turnover, although, as Table 7 indicates, there was substantial but consistent interindividual variation. The maintenance of the sex hormone and bone turnover status of all the subjects at the same levels as those on their normal diet argues strongly for the lack of effect of either the experimental diets or $\mathbf{B}$ on these variables.

The findings clearly show a marked and progressive increase in intestinal Ca retention and urinary excretion on the experimental diet which was not immediately explicable by, for example, a proportional increase in dietary $\mathrm{Ca}$ intake. These changes stabilized within the first week and the hypercalciuria was, thereafter, sustained in all subjects and remained unaffected by the supplementation with B. In contrast, Nielsen et al. (1987) report that supplementing a low-B diet with $3 \mathrm{mg} \mathrm{B} / \mathrm{d}$ reduces urinary $\mathrm{Ca}$ excretion in postmenopausal women. It is possible that diet-induced perturbations of $\mathrm{Ca}$ metabolism found in our volunteers inhibited or masked any effects of B. Increased acid load as a result of diminished vegetable and fruit intake may have contributed to the hypercalciuric effect observed, and removal of dietary inhibitors of $\mathrm{Ca}$ absorption such as phytates and oxalates could have enhanced $\mathrm{Ca}$ absorption. A study is, therefore, in progress to investigate the effect of several factors in LBD, including acidity, on $\mathrm{Ca}$ excretion and urine acidity in postmenopausal women.

The metabolic balance of $\mathrm{Mg}$ and $\mathrm{P}$ was also affected following the transition from APD to LBD. As for $\mathrm{Ca}$, this could not be attributed to changes in dietary intake of these elements (Table 3 ). The mean $\mathrm{P}$ intake decreased by about $14 \%$ and yet the women were in $P$ balance at the start of LBD and there was a steady increase in balance throughout the 6 weeks. The values in Table 8 , which are representative of those from all volunteers, reveal that the negative $\mathrm{Mg}$ balance induced by LBD was due to increased urinary excretion and also to decreased absorption, since faecal $\mathrm{Mg}$ increased progressively over the first 3 weeks and the net endogenous excretion of $\mathrm{Mg}$ into the intestinal lumen is negligible (Dreosti, 
1986). About $50 \%$ of the total intake of $\mathrm{Mg}$ was contributed by the Normacol fibre supplement but this $\mathrm{Mg}$ was present in the form of insoluble silicates. Reduced $\mathrm{Mg}$ absorption and increased urinary $\mathrm{Mg}$ excretion may have been related to an increase in $\mathrm{Ca}$ intake during the study (Lakshmanan et al. 1984; Dreosti, 1986).

The lack of any effect of a $B$ supplement on minerals, steroids and pyridinium crosslinks could not be attributed to a poor absorption of $B$ from $\mathrm{Na}_{2} \mathrm{~B}_{4} \mathrm{O}_{7}$. Analysis of urine confirmed that most of the $\mathrm{B}$ in LBD and in the supplement was rapidly absorbed and excreted in the urine (Fig. 2). A rapid turnover of B following intravenous injection has been demonstrated previously (Jansen et al. 1984). On starting the B supplementation in the present study urinary excretion of B was more than $90 \%$ of intake, which is in agreement with published findings (Kent \& McCance, 1941). This result shows that the absorption efficiency for B is very high and that urine is the main pathway for its excretion. The rapid decrease in urinary $B$ within $1 \mathrm{~d}$ of starting LBD was particularly interesting as it suggests that urinary B excretion provides an accurate reflection of B intake over the $24 \mathrm{~h}$ period of collection. It also suggests that $\mathrm{B}$ does not form strong complexes with large molecules such as proteins in the body and that it moves rapidly across membranes.

Although we did not record an effect of B in the present study, other dietary conditions may favour a response to this element. Nielsen (see Peace \& Beattie, 1991) has suggested that the duration of $\mathrm{B}$ depletion may be crucial, although to our knowledge the effect of depletion period has never been systematically studied. The duration of the present study was limited to 6 weeks for practical reasons. Whether crucial or not, the period of B depletion may have limited practical relevance, at least in developed countries, as there is no evidence of sustained $B$ depletion in human populations. The paucity of information on the $\mathbf{B}$ content of foods limits any detailed assessment of dietary $\mathbf{B}$ intake in population groups, but the average intake in the UK has been determined at $2.8 \mathrm{mg} \mathrm{B} / \mathrm{d}$ (Hamilton \& Minski, 1972). Since B is very rapidly absorbed and excreted, the body burden of this element probably fluctuates widely during a $24 \mathrm{~h}$ period, particularly in relation to the consumption of some fruit-based products, including preserves and beverages, and also to seasonal changes in diet. The degree of variability in B intake could be assessed, without extensive dietary analysis, by measuring the amount of this element in successive $24 \mathrm{~h}$ urine samples, since urinary $\mathbf{B}$ appears to reflect accurately recent dietary intake. Unfortunately, this type of information is not available.

Several recent publications (Hunt \& Nielsen, 1981, 1988; Nielsen, 1988; Nielsen et al. 1988; Hunt, 1989; Hegsted et al. 1991) indicate that interactions with $\mathrm{Mg}$, vitamin D and other nutrients are the key to the significance of $B$ as an essential element. In the case of $\mathrm{Mg}$ and $\mathrm{B}$, one element is thought to ameliorate the deficiency symptoms associated with the other. However, since B-deficient diets tend also to be deficient in $\mathbf{M g}$, such an interaction seems unlikely in free-living populations. Supplementation with physiological amounts of $\mathrm{B}$ may prove beneficial in cases of combined $\mathrm{B}$ and $\mathrm{Mg}$ deficiency but then so might supplementation with $\mathrm{Mg}$.

It is also notable that $\mathrm{B}$ concentrations are high in foods of high fibre content and recent studies indicate that diets providing a high fibre intake, as is the case with vegetarian diets, significantly reduce plasma oestradiol concentrations in pre- and postmenopausal women (Goldin et al. 1982; Barbosa et al. 1990). Fibre appears to reduce the entero-hepatic cycling of oestrogens, thus increasing their faecal excretion and reducing plasma levels of active oestrogens (Goldin et al. 1982). This evidence would appear to contradict the hypothesis that foods containing relatively large amounts of B, i.e. those of plant origin, would increase plasma oestradiol.

In conclusion, we could detect no effect of a daily $3 \mathrm{mg}$ supplement of $\mathrm{B}$ on bone mineral metabolism, bone turnover as indicated by collagen crosslink excretion or plasma sex 
steroid levels in postmenopausal women volunteers. However, LBD designed for the present study had a major influence on $\mathrm{Ca}$ absorption and excretion in postmenopausal women which may have inhibited or obscured any effect of $B$.

The authors wish to thank Dr Geraldine McNeill and Dr Peter Aggett for taking blood samples, Mrs Margaret Mitchell for assistance with the analysis of B by ICP/OES, Dr Simon Robins and Mr Sandy Duncan for help with the separation of pyridinium crosslinks by HPLC, and Mr Ian Nevison for statistical advice. Furthermore, they appreciate the constructive comments of Dr Nigel Loveridge, Dr David Reid and Dr Alison Avenell and thank Professor W. P. T. James and Dr Ian Bremner for their advice and critical review of the manuscript. This work was supported by a grant from the Scottish Home and Health Department.

\section{REFERENCES}

Barbosa, J. C., Shultz, T. D., Filley, S. J. \& Nieman, D. C. (1990). The relationship among adiposity, diet, and hormone concentrations in vegetarian and non-vegetarian postmenopausal women. American Journal of Clinical Nutrition 51, 798-803.

Beattie, J. H. \& Macdonald, A. (1991). Effect of boron on bone metabolism in rats. In Trace Elements in Man and Animals no. 7, pp. 26.29-26.30 [B. Momcilovic, editor]. Zagreb: IMI Press.

Beattie, J. H. \& Weersink, E. (1992). Borate and molybdate inhibition of catechol oestrogen and pyrocatechol methylation by catechol-O-methyltransferase. Journal of Inorganic Biochemistry 46, 153-160.

Black, D., Farquharson, C. \& Robins, S. P. (1989). Excretion of pyridinium cross-links of collagen in ovariectomized rats urinary markers for increased bone resorption. Calcified Tissue International 44, 343-347.

Bosnes, R. W. \& Taussky, H. H. (1945). On the colorimetric determination of creatinine by the Jaffe reaction. Journal of Biological Chemistry 158, 581-591.

Bremner, I. (1991). A molecular approach to the study of copper and zinc metabolism. In Trace Elements in Man and Animals no. 7, pp. 1.1-1.3 [B. Momcilovic, editor]. Zagreb: IMI Press.

Dreosti, I. E. (1986). Magnesium (review). Journal of Food and Nutrition 42, 59-67.

Fiske, C. H. \& Subbarow, Y. (1925). The colorimetric determination of phosphorous. Journal of Biological Chemistry 66(2), 375-399.

Gitelman, H.J. (1967). An improved automated procedure for the determination of calcium in biological specimens. Analytical Biochemistry 18, 521-531.

Gitelman, H. J., Hurt, C. \& Lutwak, L. (1966). An automatic spectrophotometric method for magnesium analysis. Analytical Biochemistry 14, 106-120.

Goldin, B. R., Adlercreutz, H., Gorbach, S. L., Warram, J. H., Dwyer, J. T., Swenson, L. \& Woods, M. N. (1982). Estrogen excretion patterns and plasma levels in vegetarian and omnivorous women. New England Journal of Medicine 307, 1542-1547.

Hamilton, E. I. \& Minski, M. J. (1972). Abundance of the chemical elements in man's diet and possible relations with environmental factors. Science of the Total Environment 1, 375-394.

Hegsted, M., Keenan, M. J., Siver, F. \& Wozniak, P. (1991). Effect of boron on vitamin D deficient rats. Biological Trace Element Research 28, 243-255.

Hunt, C. D. (1989). Dietary boron modified the effects of magnesium and molybdenum on mineral metabolism in the cholecalciferol-deficient chick. Biological Trace Element Research 22, 201-220.

Hunt, C. D. \& Nielsen, F. H. (1981). Interaction between boron and cholecalciferol in the chick. In Trace Elements in Man and Animals no. 4, pp. 597-600 [J. McC. Howell and J. M. Gawthorne, editors]. Canberra: Australian Academy of Science.

Hunt, C. D. \& Nielsen, F. H. (1988). Dietary boron affects calcification in magnesium and cholecalciferol deficient chicks. In Trace Elements in Man and Animals no. 6, pp. 275-276 [L. S. Hurley, C. L. Keen, B. Lönnerdal and R. B. Rucker, editors]. New York: Plenum Press.

Hutton, J. D., Jacobs, H. S. \& James, V. H. T. (1979). Steroid endocrinology after the menopause: a review. Journal of the Royal Society of Medicine 72, 835-841.

Jackson, J. F. \& Chapman, K. S. R. (1975). The role of boron in plants. In Trace Elements in Soil-plant-animal Systems, pp. 213-225 [D. J. D. Nicolas and A. R. Egan, editors]. New York: Academic Press.

Jansen, J. A., Andersen, J. \& Schou, J. S. (1984). Boric acid single dose pharmacokinetics after intravenous administration to man. Archives of Toxicology 55, 64-67.

Kent, N. L. \& McCance, R. A. (1941). The absorption and excretion of 'minor' elements by man. I. Silver, gold, lithium, boron and vanadium. Biochemical Journal 35, 837-844.

Koivistoinen, P. (editor) (1980). Mineral element composition of Finnish foods: N, K, Ca, Mg, P, S, Fe, Cu, Mn, $\mathrm{Zn}, \mathrm{Mo}, \mathrm{Co}, \mathrm{Ni}, \mathrm{Cr}, \mathrm{F}, \mathrm{Se}, \mathrm{Si}, \mathrm{Rb}, \mathrm{Al}, \mathrm{B}, \mathrm{Br}, \mathrm{Hg}, \mathrm{As}, \mathrm{Cd}, \mathrm{Pb}$ and Ash. Acta Agriculturae Scandanavica 22, Suppl. 
Lakshmanan, F. L., Rao, R. B., Kim, W. W. \& Kelsay, J. L. (1984). Magnesium intakes, balances, and blood levels of adults consuming self-selected diets. American Journal of Clinical Nutrition 40, 1380-1389.

Nielsen, F. H. (1988). Boron - an overlooked element of potential nutritional importance. Nutrition Today pp. $4-7$.

Nielsen, F. H., Hunt, C. D., Mullen, L. M.\& Hunt, J. R. (1987). Effect of dietary boron on mineral, estrogen, and testosterone metabolism in postmenopausal women. FASEB Journal 1, 394-397.

Nielsen, F. H., Mullen, L. M. \& Gallagher, S. K. (1990). Effect of boron depletion and repletion on blood indicators of calcium status in humans fed a magnesium-low diet. Journal of Trace Elements in Experimental Medicine 3, 45-54.

Nielsen, F. H., Shuler, T. R., Zimmerman, T. J. \& Uthus, E. O. (1988), Magnesium and methionine deprivation affect the response of rats to boron deprivation. Biological Trace Element Research 17, 91-107.

Paul, A. A. \& Southgate, D. A. T. (1978). McCance and Widdowson's, The Composition of Foods, 4th ed. London: H.M. Stationery Office.

Peace, H. \& Beattie, J. H. (1991). No effect of boron on bone mineral excretion and plasma sex steroid levels in healthy postmenopausal women. In Trace Elements in Man and Animals no. 7, pp. 8.1-8.2 [B. Momcilovic, editor] Zagreb: IMI Press.

Rae, M. H., Mole, P. A. \& Paterson, C. R. (1988). Evaluation of urinary oestrogen assays after the menopause and their potential for screening. Clinica Chimica Acta 176, 71-82.

Reed, M. J. \& Murray, M. A. F. (1979). The Oestrogens. In Hormones in Blood, pp. 263-353 [C. H. Gray and V. H. T. James, editors] London: Academic Press.

Robins, S. P., Duncan, A. \& Riggs, B. L. (1990). Direct measurement of free hydroxypyridinium crosslinks of collagen in urine as new markers of bone resorption in osteoporosis. In Osteoporosis pp. 465-468 [C. Christiansen and K. Overgaard, editors]. Copenhagen: Osteopress ApS.

Robins, S. P., Black, D., Paterson, C. R., Reid, D. M., Duncan, A. \& Seibel, M. J. (1991). Evaluation of urinary hydroxypyridinium crosslink measurements as resorption markers in metabolic bone diseases. European Journal of Clinical Investigation 21, 310-315.

Seibel, M. J., Duncan, A. \& Robins, S. P. (1989). Urinary hydroxypyridinium crosslinks provide indices of cartilage and bone involvement in arthritic diseases. Journal of Rheumatology 16, 964-970.

Ubelhardt, D., Schlemmer, A., Johansen, J. S., Gineyets, E. C., Christiansen, C. \& Delmas, P. D. (1991). Effect of menopause and estrogen treatment on the urinary excretion of pyridinium crosslinks. Journal of Clinical Endocrinology and Metabolism 72, 367-373. 